\title{
PENDEKATAN KOMUNIKASI ORGANISASI DALAM PENYAMPAIAN KEBIJAKAN KANTIN BEBAS 5P (PEWARNA, PENYEDAP, PEMANIS, PENGAWET DAN PERASA) DI SMP NEGERI 7 SURABAYA
}

\author{
Mohammad Insan Romadhan \\ Program Studi Ilmu Komunikasi FISIP Universitas 17 Agustus 1945 Surabaya \\ Email: insanromadhan@untag-sby.ac.id
}

Diterima : 30 Juli 2018

Disetujui : 16 Agustus 2018

Diterbitkan : 31 Agustus 2018

\begin{abstract}
Abstrak
Kebijakan merupakan hal yang selalu ada dalam setiap organisasi, kebijakan merupakan pedoman dasar dari proses berjalannya suatu organisasi, sehingga organisasi tersebut dapat berjalan dengan semestinya. Berdasarkan hal tersebut peneliti tertarik untuk meneliti implementasi pendekatan komunikasi organisasi yang dilakukan kepala sekolah dalam menyampaikan kebijakan kantin bebas 5P kepada pemilik kantin di SMP Negeri 7 Surabaya. Jenis penelitian deskriptif, informan penelitian adalah kepala sekolah dan pemilik kantin. Teknik pengumpulan datanya menggunakan wawancara, observasi dan dokumentasi, teknik analisis datanya peneliti menggunakan teknik analisis data dari Creswell. Hasil penelitian yaitu pendekatan komunikasi organisasi yang diterapkan oleh kepala sekolah SMP Negeri 7 Surabaya dalam penyampaian kebijakan kantin bebas 5P lebih condong kepada pendekatan klasik dan Pendekatan human relations
\end{abstract}

Kata Kunci: Pendekatan Komunikasi Organisasi, Kepala Sekolah, Kebijakan Kantin Bebas 5P

\begin{abstract}
Policy is always there in every organization, the policy is the basic guidelines of the process of the passage of an organization, so that the organization can run properly. Based on the foregoing researchers interested in examining the implementation of the Organization's communications approach undertaken in delivering a policy that canteen is free of 5P to the owner of the canteen in 7 th junior high school. This type of descriptive research, the informant is a headmaster and owner. The technic of collecting data using interviews, observation and documentation of the data analysis techniques, researchers using the technique of data analysis from Creswell. Results of research i.e. organizational communication approach applied by the head of the 7 th junior school in surabaya in the delivery of policies free canteen $5 P$ is leaning more to the classical approach and human relations approach.
\end{abstract}

Keywords: Organization's communications approach, free 5P Canteen policy, Headmaster

\section{PENDAHULUAN}

Kebijakan merupakan hal yang selalu ada dalam setiap kehidupan berorganisasi, tidak ada organisasi yang tidak memiliki kebijakan, hal tersebut karena kebijakan merupakan pedoman dasar dari proses berjalannya suatu organisasi, sehingga organisasi tersebut dapat berjalan dengan semestinya. Akan tetapi kebijakan dalam suatu organisasi merupakan hal yang kadang sensitif, hal tersebut dikarenakan kebijakan bersinggungan oleh banyak orang, tidak jarang kebijakan dalam suatu organisasi dapat menimbulkan kekecewaan dipihak satu sedangkan dipihak lain menimbulkan kesenangan. Organisasi atau perusahaan dituntut mampu untuk menyelesaikan permasalahan tersebut, oleh karena itu suatu organisasi selain 
harus mampu mengeluarkan kebijakan yang sesuai dengan tujuan organisasi yang sekaligus dapat diterima oleh semua pihak yang terkait dengan organisasi, organisasi juga harus mampu menyampaikan kebijakan tersebut dengan cara komunikasi yang baik, sehingga apa yang diinginkan oleh organisasi melalui kebijakan tersebut dapat tersampaikan kepada yang bersangkutan sesuai dengan apa yang memang diinginkan organisasi

Hal tersebut berlaku di semua organisasi termasuk diantaranya organisasi pendidikan seperti sekolah. Sama halnya dengan organisasi lainnya, sekolah juga memiliki kebijakankebijakan yang diperlukan untuk mengelola jalannya organisas, termasuk salah satunya adalah kebijakan kantin bebas 5P yang harus dijalankan oleh sekolah. Kantin bebas 5P yang merupakan kepanjangan dari pewarna, penyedap, pemanis, pengawet dan perasa, oleh pemerintah kota surabaya melalui dinas pendidikan dan dinas kesehatan kota surabaya mengeluarkan kebijakan bahwa kantin sekolah harus bebas dari 5P. Hal tersebut seperti dinyatakan dalam website surabaya.go.id, berikut kutipannya:

Dinas Pendidikan (Dispendik) bersama Dinas Kesehatan (Dinkes) Surabaya melakukan sebuah upaya pencegahan sekaligus pembinaan terhadap makanan yang kurang sehat di kantin-kantin sekolah. Upaya-upaya tersebut diwujudkan melalui pemberian label kepada kantin sekolah, Ikhsan, Kadispendik Surabaya mengatakan, pemberian label ini bertujuan untuk mengklasifikasikan jenis kantin yang menjual jajanan di sekolah (surabaya.go.id/akses 19 desember 2017).

Label yang diberikan pada kantin sekolah tersebut menyangkut seberapa baik tingkat kantin sekolah dalam meminimalisirkan penggunaan pewarna, penyedap, pemanis, pengawet dan perasa. Label hijau bertanda bahwa kantin tersebut terbebas dari 5P, label kuning bertanda bahwa kantin tersebut masih menjual sebagian kecil makanan yang mengandung 5P, dan label merah bertanda bahwa kantin masih menjual sebagian besar makanan yang mengandung 5P.

Kebijakan tersebut merupakan salah satu upaya yang dilakukan oleh dinas pendidikan dan dinas kesehatan kota surabaya untuk mencegah kualitas buruk generasi muda karena dampak dari makanan kurang sehat, oleh karena itu pencegahan tersebut dilakukan sedini mungkin dan di level yang paling bawah, yaitu dengan menerapkan kebijakan kantin bebas 5P di kantin-kantin sekolah. Kebijakan tersebut wajib dijalankan oleh kepala sekolah di lingkungan Surabaya, termasuk di SMP Negeri 7 Surabaya. SMP yang berlokasi di Tanjung Sadari ini sudah berdiri dari sekitar tahun 1950an. Berkaitan dengan kebijakan tersebut, hal itu menjadi kesulitan tersendiri bagi sekolah, dikarenakan penjual kantin sudah memiliki kisaran modal dan keuntungan yang sudah mereka perhitungkan, belum juga dari kebiasaan penjual yang orientasinya keuntungan dan kurang memperhatikan apakah makanan yang dijual sehat atau tidak, tentu hal tersebut bisa menjadi hal yang sensitif. Oleh karena itu komunikasi menjadi hal yang perlu diperhatikan dalam penyampaian kebijakan kantin bebas 5P di kantin sekolah, sehingga tidak menimbulkan hal-hal yang tidak diinginkan. Dengan komunikasi yang baik bisa juga meminimalisirkan kesalahpahaman antara penjual dan pihak sekolah. Implementasi komunikasi tersebut menjadi kewajiban kepala sekolah sebagai pimpinan tertinggi sekolah dalam mengkomunikasikan kepada pihak yang terkait yaitu kantin.

Komunikasi yang dilakukan dalam penyampaian kebijakan sekolah, karena hal tersebut terjadi dalam ruang lingkup organisasi, maka komunikasi yang diteliti adalah komunikasi organisasi. Organisasi yang diartikan sebagai suatu sistem, mengkoordinasi aktivitas dan mencapai tujuan bersama atau tujuan umum. Dikatakan merupakan suatu sistem 
karena organisasi itu terdiri dari berbagai bagian yang saling tergantung satu sama lain. Bila satu bagian terganggu maka akan ikut berpengaruh pada bagian lainnya (Arni, 2011:24). Berdasarkan penjelasan tersebut maka dapat diartikan bahwa unit-unit yang ada di organisasi saling bergantung satu sama lain, kaitannya dengan kebijakan organisasi dikarenakan kebijakan menyangkut dengan semua unit di organisasi, sehingga ketika kebijakan tersebut ada maka hal tersebut akan mempengaruhi unit-unit yang ada di organisasi dan dalam hal ini yaitu adanya kebijakan kantin bebas 5P. Sedangkan komunikasi organisasi menurut Goldhaber (1986) adalah proses menciptakan dan saling menukar pesan dalam satu jaringan hubungan yang saling tergantung sama lain untuk mengatasi lingkungan yang tidak pasti atau yang selalu berubah-ubah (Arni, 2011:67). Dari penjelasan tersebut dapat diartikan bahwa komunikasi merupakan penghubung antara unit-unit yang ada di organisasi, sehingga ketika adanya suatu perubahan di dalam organisasi maka komunikasi inilah yang bekerja sebagai penghubung diantara unit-unit yang ada. Termasuk kebijakan bebas 5P tersebut, dengan adanya kebijakan tersebut sekolah dituntut bisa mengelola kantin untuk dapat bebas dari 5P, agar kualitas makanan yang dijual dan dikonsumsi oleh generasi bangsa ini mendapatkan kualitas yang baik.

Dalam pandangan Nakpodia (2010) menyatakan bahwa tanpa komunikasi, organisasi apapun tidak akan menjadi seperti yang diharapkan dan tidak akan bisa mencapai tujuan secara efektif (Iriantara, Syaripudin, 2013:41). Melihat pandangan Nakpodia tersebut komunikasi menjadi hal yang penting untuk mencapai tujuan organisasi, oleh karena itu komunikasi yang dilakukan oleh kepala sekolah dalam menyampaikan kebijakannya harus efektif. Kohler (1981) juga menyatakan bahwa komunikasi yang efektif adalah penting bagi semua organisasi. Oleh karena itu, para pemimpin organisasi dan para komunikator dalam organisasi perlu memahami dan menyempurnakan kemampuan komunikasi mereka (Poppy, 2014:1). Agar kebijakan yang dikeluarkan nantinya dapat diterima oleh semua pihak, maka dibutuhkan suatu komunikasi yang sesuai. Peneliti tertarik meneliti di SMP Negeri 7 Surabaya ini dikarenakan termasuk salah satu sekolah yang sudah lama berdiri dan sedang berproses menuju kantin bebas 5P. Oleh karena itu peneliti tertarik untuk melihat implementasi pendekatan komunikasi organisasi yang dilakukan dalam menyampaikan kebijakan kantin bebas 5P kepada pemilik kantin di SMP Negeri 7 Surabaya.

Pendekatan komunikasi organisasi menurut Miller terbagi menjadi enam yang dapat di implementasikan, classical approaches, human relations approaches, human resources approaches, systems approaches, cultural approaches dan critical approaches (Miller, 2012:xvi). Miller menyebutkan classical approaches, human relations approaches dan human resources approaches adalah pendekatan dengan mempertimbangkan perspektif mengenai bagaimana komunikasi organisasi berjalan dalam suatu organisasi, sedangkan systems approaches, cultural approaches dan critical approaches dianggap sebagai pendekatan komunikasi organisasi kontemporer, mengenai bagiamana kita dapat menggambarkan, memahami, menjelaskan dan mengkritik bagaimana komunikasi organisasi dalam suatu organisasi.

\section{METODE PENELITIAN}

Pendekatan yang digunakan dalam penelitian ini adalah pendekatan kualitatif, Pendekatan kualitatif yaitu pendekatan sebagai prosedur penelitian yang menghasilkan data deskriptif berupa kata-kata tertulis atau lisan dari orang-orang dan prilaku yang dapat diamati (Moloeng. 2002). Sedangkan jenis penelitian menggunakan jenis penelitian deskriptif, yaitu menggambarkan atau menganalisis suatu hasil penelitian tetapi tidak digunakan untuk membuat kesimpulan yang lebih luas (Sugiyono, 2009). Subjek penelitian ini adalah kepala sekolah SMP Negeri 7 Surabaya, objek penelitiannya SMP Negeri 7 
Surabaya, sedangkan informan penelitian adalah kepala sekolah SMP Negeri 7 Surabaya. Teknik pengumpulan datanya menggunakan wawancara, observasi dan dokumentasi, dimana peneliti menanyakan, melihat dan mengamati bagaimana pendekatan komunikasi organisasi yang diterapkan dalam menyampaikan kebijakan kantin bebas 5P. Teknik analisis datanya peneliti menggunakan teknik analisis data dari Creswell. Pendekatan dari Creswell bertahap, linier dan hierarkis yang dibangun dari bawah ke atas, tetapi dalam prakteknya tidak menutup kemungkinan pendekatan ini lebih interaktif, beragam dan saling berhubungan dan tidak selalu sesuai dengan susunan yang telah disajikan. Dalam penelitian kualitatif, peneliti adalah instrumen kunci, oleh karena itu, peneliti harus memiliki bekal teori dan wawasan yang luas jadi bisa bertanya, menganalisis, dan mengkonstruksi obyek yang diteliti menjadi lebih jelas. (Creswell, 2014)

\section{HASIL DAN PEMBAHASAN}

Sebelum melihat implementasi pendekatan komunikasi organisasi yang diterapkan di SMP Negeri 7 Surabaya terkait dengan penyampaian kebijakan kantin bebas 5P, peneliti membedah terlebih dahulu mengenai enam pendekatan tersebut, pertama pendekatan klasik, pendekatan ini menurut Katherine Miller dalam hal konten komunikasinya adalah: The content of communication in these organizations is restricted to work-related issues. In the classical theories we have considered, there are certain things that should be talked about and certain things that should not be talked about in the organization (Miller, 2012:30). (Konten komunikasinya dalam organisasi-organisasi ini dibatasi untuk isu-isu yang terkait dengan pekerjaan. Dalam teori-teori klasik yang telah kita membahas, ada hal-hal tertentu yang harus dibicarakan dan hal-hal tertentu yang tidak harus dibicarakan dalam organisasi). Berdasarkan penjelasan di atas bahwa konten komunikasi yang dilakukan dalam organisasi dalam pendekatan klasik ini dibatasi kepada masalah tugas dan pekerjaan dalam organisasi. Dalam pendekatan klasik ini menekankan bahwa ada yang perlu dan ada yang tidak perlu dibicarakan dalam organisasi. Prinsip ini menunjukkan bahwa karyawan harus fokus pada tujuan organisasi, bukan pada kebutuhan dan keinginan individu mereka sendiri.

Arah komunikasi dalam pendekatan klasik menurut Katherine Miller yaitu: in these classical theories, the vast majority of communication in the organization flows downward in the form of orders, rules, and directives (Miller, 2012:30). (dalam teori klasik ini, sebagian besar komunikasi dalam organisasi mengalir ke bawah dalam bentuk perintah, peraturan dan petunjuk). Berdasarkan penjelasan tersebut disebutkan bahwa dalam pendekatan klasik arah komunikasi dalam organisasi sebagian besar vertikal dari atas ke bawah yang biasanya berbentuk perintah, aturan, dan arahan dari pimpinan organisasi kepada anggota organisasi. Dalam pendekatan klasik ini sangat jarang ditemukan komunikasi dalam organisasi yang bersifat tidak berkaitan dengan tugas.

Saluran komunikasi yang digunakan dalam pendekatan klasik menurut Katherine Miller adalah sebagai berikut: classical theories emphasize the permanence of rules and procedures for efficient organizational functioning, these organizations will probably also rely heavily on written communication in the form of employee handbooks, instructions, mission statements, rules, and performance evaluations (Miller, 2012:31). (teori-teori klasik menekankan kekekalan peraturan dan prosedur untuk fungsi efisiensi organisasi, organisasiorganisasi ini akan mungkin juga bergantung banyak pada komunikasi tertulis dalam bentuk buku pegangan karyawan, petunjuk, pernyataan misi, aturan, dan evaluasi kinerja). Berdasarkan penjelasan tersebut dapat diartikan bahwa saluran komunikasi dalam pendekatan klasik biasanya tertulis seperti dalam bentuk buku pegangan karyawan, petunjuk, pernyataan misi, aturan, dan evaluasi kinerja. 
Gaya komunikasi dalam pendekatan klasik ini menurut Katherine Miller disebutkan bahwa:

We have already noted that communication will tend to be top-down, written, and task-related. It is also likely that the tone or style of that communication will be highly formal. For example, forms of address will often be distant rather than familiar (for example, Mr. and Ms. Rather than first names). Titles will be used (such as supervisor, secretary, or administrative assistant) to separate managers from other employees. The vocabulary chosen for messages will avoid slang and colloquial terms, opting instead for highly standard language (Miller, 2012:31). (Kita telah menekankan bahwa komunikasi akan cenderung atas ke bawah, tertulis dengan tugas yang terkait. Hal ini juga mungkin bahwa nada atau gaya komunikasi yang dilakukan akan sangat formal. Sebagai contoh, bentuk teguran akan sering jauh dari teguran akrab (misalnya, Mr dan Ms. Rather kemudian namanya). jabatan akan digunakan (seperti supervisor, Sekretaris, atau Asisten Administrasi) untuk membedakan manajer dari karyawan lain. Kosa-kata yang dipilih untuk berkomunikasi akan menghindari istilah sehari-hari, memilih sebaliknya untuk bahasa sangat baku). Berdasarkan penjelasan tersebut disebutkan bahwa gaya komunikasi akan cenderung formal seperti memanggil dan menyapa dengan sangat hormat seperti bapak, ibu. Kemudian bisa juga diberi embel-embel jabatan dalam berkomunikasi untuk membedakan atasan dan bawahan.

Pendekatan human relations dapat diartikan sebagai hubungan manusia ataupun hubungan antar manusia manusia, dalam organisasi teori hubungan manusia ini menekankan pada pentingnya individu dan hubungan sosial dalam kehidupan organisasi. Manusia sebagai anggota organisasi adalah merupakan inti dari organisasi sosial, manusia terlibat dalam tingkah laku organisasi. Tanpa manusia organisasi tidak akan ada, oleh karena itu faktor manusia dalam organisasi haruslah mendapat perhatian dan tidak dapat diabaikan seperti halnya dengan teori klasik (Arni, 2011: 39). Berdasarkan paparan di atas dapat diartikan bahwa dalam organisasi tidak melulu hanya dibutuhkan sebuah peraturan-peraturan, birokrasi, dan pembagian tugas-tugas seperti yang dituangkan dalam pendekatan klasik, akan tetapi pendekatan lebih kepada manusianya dalam organisasi tersebut juga menjadi sangat penting, karena apapun itu yang menjalankan aktifitas dalam organisasi tersebut adalah manusia. Karena itu hubungan sosial ataupun hubungan antar manusia di dalam organisasi juga memiliki fungsi penting dalam kelancaran organisasi seperti yang disebutkan dalam pendekatan human relations.

Mengenai komunikasi dalam pendekatan human relations ini untuk konten komunikasinya disebutkan bahwa: In human relations organizations, task-related communication still exists, but it is accompanied by communication that attempted to maintain the quality of human relationships within the organization-maintenance communication (Miller, 2012:51). (Di organisasi human relations, tugas yang terkait komunikasi masih ada, tetapi ini disertai dengan komunikasi yang berusaha untuk menjaga kualitas hubungan manusia dalam organisasi - pemeliharaan komunikasi). Penjelasan dari kutipan di atas dapat dipaparkan sebagai berikut yaitu pendekatan human relations dalam organisasi mengenai konten komunikasinya walaupun ada yang sama dengan pendekatan klasik yaitu adalah mengenai komunikasi yang terjalin karena suatu tugas dalam organisasi, akan tetapi di pendekatan human relations ini konten komunikasinya juga terdapat komunikasi yang terjalin karena kedekatan dalam hal meningkatkan hubungan antar manusia di dalam anggota organisasi tersebut.

Arah komunikasinya disebutkan juga, bahwa: A human relations approach does not eliminate this need for vertical information flow but instead adds an emphasis on horizontal communication. As discussed earlier in this chapter, human relations theorists believe that 
an important aspect of need satisfaction is communication among employees, so interaction that flows horizontally among employees is just as important as downward communication in the accomplishment of organizational goals (Miller, 2012:52) (Pendekatan human relations tidak menghilangkan pentingnya arus informasi vertikal tetapi sebaliknya menambahkan penekanan pada komunikasi horisontal. Seperti telah dibahas sebelumnya dalam bab ini, teori hubungan manusia percaya bahwa aspek penting dari kepuasan kebutuhan komunikasi antara karyawan, sehingga interaksi yang mengalir horizontal antara karyawan sama pentingnya dengan menurun komunikasi dalam pencapaian tujuan organisasi). Penjelasan dari kutipan di atas yaitu pendekatan human relations dalam organisasi mengenai arah komunikasinya adalah dalam pendekatan human relations tidak menghilangkan akan kebutuhan arah informasi yaitu komunikasi vertikal dari atas, tetapi menambahkan pada komunikasi horizontal juga. Dalam pendekatan human relations percaya bahwa kebutuhan komunikasi antar karyawan juga menjadi aspek penting selain komunikasi ke bawah dalam mencapai tujuan organisasi.

Saluran komunikasinya disebutkan juga, bahwa: In the human relations approach, in contrast, face-to-face communication takes center stage. This channel of interaction allows for more immediate feedback and more consideration of nonverbal cues. Thus, face-to-face communication is more appropriate for addressing the human needs emphasized in the human relations approach (Miller, 2012:51). (Dalam pendekatan human relations, sebaliknya, komunikasi secara tatap muka menjadi yang utama. Cara komunikasi ini memungkinkan interaksi lebih banyak umpan balik langsung dan juga isyarat nonverbal menjadi lebih banyak. Dengan demikian, tatap muka komunikasi lebih tepat untuk menangani kebutuhan manusia yang ditekankan dalam pendekatan hubungan manusia). Penjelasan dari kutipan di atas yaitu saluran komunikasinya lebih ke arah tatap muka, karena komunikasi secara tatap muka dapat memungkinkan untuk menerima umpan balik lebih cepat dan dapat diperkuat oleh bahasa non verbal dari orang yang diajak berkomunikasi.

Gaya komunikasi disebutkan juga bahwa: A human relations organization is likely to want to break down the status differential between managers and employees as a means of satisfying social needs. Thus, it is likely that informal communication-with less emphasis on titles, "business" dress, and bureaucratized language-will be emphasized (Miller, 2012:53). (Organisasi human relations ingin memecah status diferensial atau perbedaan antara manajer dan karyawan sebagai sarana untuk memuaskan kebutuhan sosial. Jadi, lebih kepada komunikasi informal - dengan mengurangi penekanan terhadap jabatan). Pada kutipan diatas dapat dijelaskan bahwa gaya komunikasinya bertolak belakang dengan pendekatan klasik yang lebih kearah komunikasi formal yang memperhatikan mengenai standart kesopanan dan profesionalisme, dalam pendekatan human relations gaya komunikasinya justru cenderung ingin memecah perbedaan status antara pimpinan dan bawahan dalam hal sebagai sarana pemuas kebutuhan sosial.

Pendekatan human resources konten komunikasi yang dilakukan dalam organisasi yang dibicarakan berupa tugas, sosial dan inovasi dari sumber daya dalam anggota organisasi. Kemudian mengenai arus komunikasi dalam pendekatan human resources menurut Miller yaitu: In a human resources organization, the goal is to encourage the flow of ideas from all locations throughout the organization. Thus, in the simplest sense, communication in this organizational approach will include all directional flowsdownward, upward, horizontal, and diagonal (Miller, 2012:52). (Dalam sebuah organisasi sumber daya manusia, tujuannya adalah untuk mendorong aliran gagasan dari semua lokasi di seluruh organisasi. Dengan demikian, dalam arti yang paling sederhana, komunikasi dalam pendekatan organisasi ini akan mencakup semua arah arus-bawah, ke atas, horisontal, dan diagonal). 
Saluran komunikasinya menggunakan semua saluran komunikasi. Sedangkan gaya komunikasi menurut miller yaitu: human resources organizations have the dual goals of enhancing organizational effectiveness and fulfilling human needs. On the needs side of the equation, an informal style is most likely to satisfy needs for affiliation. On the organizational effectiveness side, an informal style will also probably serve better than a formal one because employees will probably feel more comfortable contributing in a relatively informal manner (Miller, 2012:53). (organisasi sumber daya manusia memiliki tujuan ganda meningkatkan efektivitas organisasi dan memenuhi kebutuhan manusia. Pada kebutuhan sisi persamaan, gaya informal yang paling mungkin untuk memenuhi kebutuhan afiliasi. Di sisi efektivitas organisasi, gaya informal juga mungkin melayani lebih baik daripada yang formal karena karyawan mungkin akan merasa berkontribusi lebih nyaman dengan cara yang relatif informal)

Pendekatan sistem ini memandang organisasi sebagai suatu sistem yang semua bagian berinteraksi dan setiap bagian mempengaruhi lainnya. Dalam pendekatan ini, komunikasi membuat sistem tersebut vital dan tetap hidup. Karena jika suatu sistem harus bertahan, maka semua bagian-bagiannya harus dikoordinasikan dan semua kegiatannya harus disingkronkan, sehingga komunikasi menjadi penting. Komunikasi akan menghubungkan berbagai bagian dengan bagian lainnya dan menghasilkan banyak gagasan baru (Masmuh, 2010: 43)

Pendekatan kultural adalah sebuah pendekatan yang memandang bahwa organisasi sebagai satu kesatuan sosial atau kultur. Pendekatan kultural melihat organisasi dan para pekerjanya memiliki seperangkat nilai-nilai dan tujuan yang sama (Masmuh, 2010: 43). Dalam pendekatan kultural ini, kultur dalam organisasi dianggap sebagai alat untuk mencapai efektifitas organisasi. Akan tetapi anggota organisasi tidak akan serta merta mengikuti kultur yang ada dalam organisasi, anggota organisasi dalam bertindak memilih berdasarkan kepercayaan, nilai dan proses yang ia anut. Oleh karena itu organisasi harus memiliki kemampuan mempersuasi anggotanya agar memiliki kesamaan dalam hal-halnya yang ada dalam kultur organisasi. Dengan demikian tujuan perusahaan dapat terwujud dengan efektif.

Pendeketan kritis adalah sebuah pendekatan yang menekankan pada tujuan organisasi untuk mengangkat suara-suara yang terpinggirkan dalam sebuah organisasi. Dalam pendekatan kritis ini isu yang muncul seperti yang disebutkan oleh Katherine Miller (2012) adalah: (1)Certain social structures and processes lead to fundamental imbalances power, (2)These imbalances of power lead to alienation and oppression for certain social classes and groups, (3)The role of critical theorist is to explore and uncover these imbalances and bring them to the attention of the oppressed group. Disebutkan bahwa isu dalam teori kritis menyangkut (1)Struktur sosial dan proses tertentu menyebabkan daya ketidakseimbangan. (2)Ketidakseimbangan kekuasaan ini menyebabkan keterasingan dan penindasan untuk kelas sosial dan kelompok tertentu. (3)Peran teori kritis adalah untuk mengeksplorasi dan menemukan ketidakseimbangan ini dan memberikan perhatian kepada kelompok tertindas.

Pada penelitian sebelumnya dengan judul strategi komunikasi organisasi biro surabaya trade services di pt. bank central asia tbk. dalam mengkomunikasikan kaizen sebagai budaya organisasi yang baru, dipenelitian tersebut pendekatan yang digunakan untuk melihat komunikasi organisasi pimpinan dalam menyampaikan suatu kebijakan atau informasi kebawahan dengan menggunakan pendekatan komunikasi atas ke bawah saja yang mengacu pada konsep Clampitt, DeKoch, dan Cashman (2000) yang menjelaskan mengenai strategi komunikasi top-down. Sedangkan pada penelitian yang akan dilakukan oleh peneliti yaitu melihat komunikasi organisasi pimpinan dalam menyampaikan suatu kebijakan dengan mmenggunakan pendekatan komunikasi organisasi menurut Miller, karena peneliti 
beranggapan bahwa penyampaian kebijakan tidak cukup dilihat hanya dengan melihat komunikasi dari atas ke bawah saja seperti pada penelitian yang dilakukan oleh Grace, akan tetapi perlu dilakukan untuk melihat juga seperti konten komunikasinya, saluran komunikasi dan gaya komunikasinya.

Pada penelitian ini berdasarkan hasil penjelasan mengenai keenam pendekatan komunikasi organisasi, maka untuk mengidentifikasi pendekatan komunikasi organisasi dapat dilihat dari empat komponen yaitu konten komunikasi yang dibicarakan, arah komunikasinya, saluran komunikasi dan gaya komunikasinya. Sedangkan melihat implementasi yang dilakukan oleh Kepala Sekolah SMP Negeri 7 Surabaya, mengenai konten komunikasinya ketika menyampaikan kebijakan mengenai kantin bebas 5P berdasarkan hasil wawancara sebagai berikut:

Langsung saya sampaikan, tidak perlu basa basi, karena memang itu kebijakan sekolah yang harus diterapkan (Wawancara, Kepala Sekolah SMP Negeri 7 Surabaya, 3 Januari 2018).

Berdasarkan hasil wawancara tersebut dapat dikatakan bahwa konten komunikasi dalam penyampaian kebijakan kantin bebas 5P yang dilakukan oleh kepala sekolah hanya menyangkut hal yang terkait hal utama saja tanpa harus didahului oleh hal-hal yang lain, seperti basa-basi dan lain sebagainya. Hal tersebut diperkuat oleh apa yang disampaikan oleh pemilik kantin, berikut kutipan wawancaranya:

Iya mas, langsung diberitahu jika ada peraturan tersebut dan kita tidak boleh menjual bahan-bahan yang dilarang oleh sekolah (Wawancara, Pemilik Kantin, 4 Januari 2018).

Berdasarkan dari hasil wawancara tersebut dapat disimpulkan mengenai konten komunikasi dalam penyampaikan kebijakan kantin bebas 5P yang dilakukan oleh kepala sekolah SMP Negeri 7 Surabaya lebih menekankan pada hal-hal yang utama saja atau dapat dikatakan lebih kepada berbicara mengenai tugas-tugas tanpa membicarkan hal lainnya. Maka dari itu konten komunikasinya lebih condong kepada pendekatan komunikasi organisasi klasik.

Komponen berikut yaitu arah komunikasi, arah komunikasi organisasi yang dilakukan oleh kepala sekolah SMP Negeri 7 Surabaya berdasarkan wawancara sebagai berikut:

Saya sampaikan kepada pemilik-pemilik kantin dan saya beritahukan batas waktu mengenai kapan kebijakan kantin bebas 5P ini diterapkan. Nanti disitu saya memberikan penjelasan mengenai kebijakan kantin bebas 5P. Ya, ketika ada yang menanyakan saya jawab, saya jelaskan apa yang mereka belum memahami (Wawancara, Kepala Sekolah SMP Negeri 7 Surabaya, 3 Januari 2018).

Berdasarkan dari hasil wawancara tersebut dapat dijelaskan mengenai arah komunikasi yang dilakukan oleh kepala sekolah SMP Negeri 7 Surabaya dalam menyampaikan kebijakan kantin bebas 5P lebih kepada arah komunikasi atas bawah dengan cara memberikan penjelasan kepada pemilik kantin, selain itu pemilik kantin juga diberikan kesempatan untuk menanyakan mengenai kantin bebas 5P, sehingga arah komunikasinya 
juga ada yang dari bawah ke atas. Hal tersebut juga diperkuat oleh apa yang disampaikan oleh pemilik kantin, berikut kutipan wawancaranya:

Iya, kita dikumpulkan diruangan kemudian dijelaskan mengenai kebijakan tersebut mas, kita juga menanyakan apa yang menurut kita kurang jelas (Wawancara, Pemilik Kantin, 4 Januari 2018).

Dari kutipan wawancara tersebut dapat dijelaskan bahwa pemilik kantin diberikan kesempatan untuk menyampaikan apa yang harus disampaikan dan kepala sekolah juga memberikan kesempatan yang sama. Berdasarkan hal tersebut arah komunikasi ada dua yang diterapkan yaitu dari atas ke bawah yaitu dari kepala sekolah ke pemilik kantin dan dari bawah ke atas yaitu dari pemilik kantin ke kepala sekolah, maka dari itu dilihat dari arah komunikasinya lebih condong kepada pendekatan komunikasi organisasi human relations.

Kompenen ketiga dalam pendekatan komunikasi organisasi yaitu saluran komunikasi, saluran komunikasi organisasi yang dilakukan oleh kepala sekolah SMP Negeri 7 Surabaya berdasarkan wawancara sebagai berikut:

Iya, tatap muka langsung, saya kumpulkan pemilik-pemilik kantin, kemudian saya sampaikan langsung mengenai kebijakan kantin bebas 5P yang akan diterapkan di sekolah (Wawancara, Kepala Sekolah SMP Negeri 7 Surabaya, 3 Januari 2018).

Berdasarkan hasil kutipan wawancara tersebut dapat dijelaskan mengenai saluran komunikasi yang diterapkan adalah melalui tatap muka langsung, artinya tidak melalui perantara orang lain, akan tetapi kepala sekolah langsung menjelaskan dan bertemu langsung secara tatap muka kepada pemilik kantin. Hal tersebut diperkuat oleh apa yang disampaikan oleh pemilik kantin, berikut kutipan wawancaranya:

Iya, kita dikumpulkan diruangan kemudian dijelaskan mengenai kebijakan tersebut mas, kita juga menanyakan apa yang menurut kita kurang jelas (Wawancara, Pemilik Kantin, 4 Januari 2018).

Dari kutipan wawancara tersebut dapat dijelaskan bahwa pemilik kantin ditemui langsung oleh kepala sekolah untuk diberikan penjelasan mengenai kebijakan kantin bebas 5P. Berdasarkan hal tersebut pendekatan komunikasi organisasi yang diterapkan oleh kepala sekolah mengenai saluran komunikasi lebih condong kepada pendekatan komunikasi organisasi human relations.

Komponen terakhir yaitu gaya komunikasi, melihat gaya komunikasi yang diterapkan oleh kepala sekolah SMP Negeri 7 Surabaya berdasarkan wawancara sebagai berikut:

Secara formal, jadi saya undang pemilik kantin untuk saya berikan penjelasan mengenai kebijakan kantin bebas 5P (Wawancara, Kepala Sekolah SMP Negeri 7 Surabaya, 3 Januari 2018).

Berdasarkan hasil kutipan wawancara tersebut dapat dijelaskan mengenai gaya komunikasi yang diterapkan lebih kepada situasi yang formal, artinya penyampaian kebijakan kantin bebas 5P tersebut dilaksanankan dalam situasi yang formal. Hal tersebut diperkuat oleh apa yang disampaikan oleh pemilik kantin, berikut kutipan wawancaranya: 
Kita diundang rapat mas sama kepala sekolah, terus disampaikan kalau kita gak boleh berjualan apa yang dilarang oleh sekolah (Wawancara, Pemilik Kantin, 4 Januari 2018).

Dari kutipan wawancara tersebut dapat dijelaskan bahwa pemilik kantin diundang oleh kepala sekolah dalam nuasan rapat, dan hal tersebut menunjukkan situasi yang formal dalam penyampaian kebijakan kantin bebas 5P. Berdasarkan hal tersebut pendekatan komunikasi organisasi yang diterapkan oleh kepala sekolah mengenai gaya komunikasi lebih condong kepada pendekatan komunikasi organisasi klasik.

\section{KESIMPULAN}

Pendekatan komunikasi organisasi yang diterapkan oleh kepala sekolah SMP Negeri 7 Surabaya dalam penyampaian kebijakan kantin bebas 5P berdasarkan dari empat komponen konten komunikasi, arah komunikasi, saluran komunikasi dan gaya komunikasi lebih condong kepada pendekatan klasik dan human relations, dengan rincian dalam konten dan gayanya kepala sekolah lebih condong kepada pendekatan komunikasi organisasi klasik, sedangkan untuk arah komunikasi dan saluran komunikasi lebih condong kepada pendekatan komunikasi organisasi human relations.

\section{REFERENSI}

Cresswell, John W (2014). Research Design Pendekatan Kualitatif, Kuantitatif dan Mixed, Diterjemahkan oleh Achmad Fawaid. Yogyakarta: Pustaka Pelajar.

Sugiyono (2009). Metode Penelitian Kuantitatif dan Kualitatif. Bandung: Alfabeta

Masmuh, Abdullah (2010). Komunikasi Organisasi dalam Perspektif teori dan praktek. Malang: UMM Press

Miller, katherine (2012). organizational communication approaches and processes. United States: Wadsworth Cengage Learning.

Moloeng, Lexy (2002). Metodologi Penelitan Kualitatif. Bandung: Remaja Rosdakarya.

Muhammad, Arni (2011). Komunikasi Organisasi. Jakarta: Bumi Aksara

Poppy Ruliana (2014). Komunikasi Organisasi Teori dan Studi Kasus. Jakarta: RajaGrafindo Persada

(2014). Label Hijau, Indikasi Kantin Sehat Bebas Zat Kimia Berbahaya diperoleh dari (www.surabaya.go.id/berita/3405-label-hijau--indikasi-kantin-sehatbebas-zat-kimia-berbahaya) 